\title{
Effect of Accelerated-Aging Conditions on the Dissolution Stability of Ciprofloxacin Tablets
}

\author{
Noelia L. Gonzalez Vidal',2*, Marta I. V. Brevedan', \\ María A. Varillas ${ }^{1}$, Laura D. Simionato ${ }^{2}$, \\ and Maria T. Pizzorno ${ }^{1,2}$ \\ 'Cátedra Control de Calidad de Medicamentos, Departamento de Biología, \\ Bioquímica y Farmacia, Universidad Nacional del Sur, San Juan 670, \\ B8000ICN Bahía Blanca, Argentina \\ ${ }^{2}$ Cátedra Control de Calidad de Medicamentos, Facultad de Farmacia y Bioquímica, \\ Universidad de Buenos Aires, Junín 956, C1113AAD Ciudad de Buenos Aires, Argentina
}

\begin{abstract}
The aim of the present study was to evaluate and compare the influence of accelerated-aging conditions on the drug content and in vitro dissolution stability of eleven different ciprofloxacin (CIP) 500-mg tablets obtained from pharmacies and hospitals in Argentina. CIP, a Class II/IV drug in the Biopharmaceutics Classification System, is a fluoroquinolone antibiotic agent used in the treatment of bacterial infections. CIP content was evaluated following USP (1) specifications. Dissolution efficiency (DE) was calculated from dissolution profiles that were performed according to the British Pharmacopoeia monograph for CIP tablets (2). This determination was performed at time zero and after three (3M) and six months (6M) of storage, according to $\mathrm{ICH}$ accelerated-aging conditions $\left(40^{\circ} \mathrm{C} / 75 \% \mathrm{RH}\right)$. Each formulation was compared with the reference at the specified times, using ANOVA in terms of DE and similarity factor $f_{2}$. Furthermore, ANOVA for DE values was used to evaluate the effect of aging conditions on the dissolution stability within each formulation. Although the storage conditions examined in the study affected the dissolution behavior of all CIP formulations, they did not have a significant effect on chemical stability, with the exception of one formulation that showed undesirable performance in both chemical and dissolution stability.
\end{abstract}

\section{INTRODUCTION}

$$
\begin{aligned}
& \text { iprofloxacin (CIP), 1-cyclopropyl-6-fluoro-1, } \\
& \text { 4-dihydro-4-oxo-7-(1-piperazinyl)-3- } \\
& \text { quinolinecarboxilic acid (3), is a broad-spectrum }
\end{aligned}
$$
fluoroquinolone antibacterial agent used in the treatment of various bacterial infections caused by gram-positive and gram-negative microorganisms, including strains resistant to aminoglycosides and cephalosporines (4). It is the recommended drug of choice for the treatment of infections of the respiratory and urinary tracts, middle ear, paranasal sinuses, abdomen, skin, and soft tissue. Based on the Biopharmaceutics Classification System (BCS) (5), CIP can be classified as a Class II/IV drug (6). For these substances, dissolution is one of the rate-limiting steps to absorption.

Studies on the stability of drug formulations have mainly been concerned with chemical decomposition. Moreover, the different excipients of a formulation may interact during exposure to high temperatures or high humidity, reducing the in vitro dissolution, an important quality attribute of a solid oral dosage form (7-9).

Dissolution Stability is a term that refers to the retention of the dissolution characteristics of a solid oral dosage form from the time of manufacture to its expiration date

${ }^{*}$ Corresponding author.
(3). Dissolution stability is considered a critical parameter not only from the standpoint of quality control, but also for the impact on the bioavailability of the product, because significant changes of the in vitro release profile during storage may affect its bioavailability. During aging, the absence of dissolution changes provides some assurance that the bioavailability remains intact.

The release characteristics of tablets exposed to aging conditions of temperature and humidity may be reduced. Our research attempted to evaluate and compare the influence of accelerated-aging conditions $\left(40^{\circ} \mathrm{C} / 75 \% \mathrm{RH}\right)$ on the drug content and in vitro dissolution stability of eleven different formulations available in the Argentinean market, during six months of storage. The formulations contained the same amount of drug substance but different types or amounts of excipients. Aging conditions could affect the dissolution stability of these formulations in a different manner, playing an important role in drug bioavailability and interchangeability of the products during the shelf life.

\section{MATERIALS AND METHODS \\ Reagents and Samples}

Analytical grade phosphoric acid and HPLC grade triethylamine and acetonitrile were used (J.T.Baker, USA). Distilled water was used as the dissolution medium, 
Table 1. Formulation Compositions

\begin{tabular}{|c|c|}
\hline Formula & Composition \\
\hline I & Lactose; sterilizable maize starch; magnesium stearate \\
\hline II & $\begin{array}{l}\text { Lactose } 114.25 \mathrm{mg} \text {; sodium starch glycolate } 38.5 \mathrm{mg} \text {; colloidal silicon dioxide } 10 \text { mg; magnesium stearate } 25 \mathrm{mg} \text {; } \\
\text { hydroxypropyl methylcellulose } 7.7 \mathrm{mg} \text {; titanium dioxide } 5.17 \mathrm{mg} \text {; talc } 2.58 \mathrm{mg} \text {; polyethylene glycol } 2.01 \mathrm{mg}\end{array}$ \\
\hline III & Not declared \\
\hline IV & Not declared \\
\hline V & $\begin{array}{l}\text { Lactose; sterilizable maize starch; povidone; methylcellulose; magnesium stearate; hydroxypropyl methylcellulose; } \\
\text { polyethylene glycol 6000; diethyl phthalate }\end{array}$ \\
\hline $\mathrm{Vl}^{a}$ & $\begin{array}{l}\text { Microcrystalline cellulose; sterilizable maize starch; povidone; colloidal silicon dioxide; magnesium stearate; hydroxypropyl } \\
\text { methylcellulose; polyethylene glycol 4000; titanium dioxide }\end{array}$ \\
\hline VII & $\begin{array}{l}\text { Sodium starch glycolate; microcrystalline cellulose; colloidal silicon dioxide; magnesium stearate; hydroxypropyl } \\
\text { methylcellulose; titanium dioxide; triacetin; polyethylene glycol } 6000\end{array}$ \\
\hline VIII & Not declared \\
\hline IX & $\begin{array}{l}\text { Sodium starch glycolate } 38 \text { mg; magnesium stearate } 8.0 \text { mg; microcrystalline cellulose } 126.0 \text { mg; hydroxypropyl } \\
\text { methylcellulose } 22.11 \mathrm{mg} \text {; polyethylene glycol } 60002.02 \mathrm{mg} \text {; titanium dioxide } 8.70 \mathrm{mg} \text {; talc } 4.04 \text { mg }\end{array}$ \\
\hline $\mathrm{X}$ & Not declared \\
\hline XI & $\begin{array}{l}\text { Sodium starch glycolate } 50 \mathrm{mg} \text {; microcrystalline cellulose } 160.60 \mathrm{mg} \text {; colloidal silicon dioxide } 0.80 \text { mg; magnesium stearate } \\
6.40 \mathrm{mg} \text {; hydroxypropyl methylcellulose } 11.97 \mathrm{mg} \text {; titanium dioxide } 5.32 \mathrm{mg} \text {; triacetin } 1.71 \mathrm{mg} \text {; polyethylene glycol } 6000 \\
1 \mathrm{mg}\end{array}$ \\
\hline
\end{tabular}

${ }^{a}$ Reference formulation

and HPLC grade water was used for chromatographic determinations.

CIP hydrochloride monohydrate reference standard was purchased from INAME (ANMAT, Argentina).

Eleven CIP immediate-release tablet formulations, manufactured by different pharmaceutical companies, were purchased from pharmacies in Bahía Blanca city (Argentina), with the exception of formulations IX and X, which were kindly provided by local hospitals. They all contained 500 mg CIP (as hydrochloride monohydrate) but different excipient compositions (Table 1). All tests were performed within product expiration dates, which were similar among brands.

\section{Assay}

The effect of aging conditions on the chemical stability of CIP was examined using HPLC according to the USP monograph for CIP tablets (1). The decrease in the CIP peak area and the appearance of new peaks were monitored in each run for all tested tablets, but only the CIP peak area was quantified. Chemical stability of CIP in the stressed and fresh tablets was examined against a CIP reference standard, which was run simultaneously every time samples were evaluated.

Reversed-phase HPLC was performed on a system consisting of a quaternary gradient pump (Spectra System P4000), a vacuum membrane degasser (Spectra System
SCM1000), a Rheodyne injector (model 9125) with a 20- $\mu \mathrm{L}$ loop, an oven (Eldex CH-150), a UV-vis detector (Spectra System UV2000) set at $278 \mathrm{~nm}$, and a chromatography workstation (ChromQuest).

Mobile phase consisted of a mixture of $0.025 \mathrm{M}$ phosphoric acid, previously adjusted with triethylamine to a pH of $3.0 \pm 0.1$, and acetonitrile (87:13). Fresh mobile phase was prepared daily, filtered through a 47-mm nylon membrane $(0.45-\mu \mathrm{m}$ pore size, $\mu$ clar, Argentina), and vacuum-degassed before use. Separation was performed at $30^{\circ} \mathrm{C}$ on a Waters Spherisorb ODS (Hypersil) C18 reversed-phase column, $10-\mu \mathrm{m}$ particle size, $250 \times 4.6 \mathrm{~mm}$ i.d. The column was equilibrated for at least 45 min with mobile phase flowing through the chromatographic system before starting the assay. All analyses were performed under isocratic conditions at a $0.9 \mathrm{~mL} / \mathrm{min}$ flow rate.

Standard and sample solutions were prepared on a weight basis using a degassed mixture of $0.025 \mathrm{M}$ phosphoric acid, previously adjusted with triethylamine to a pH of $2.0 \pm 0.1$, and acetonitrile (87:13) as diluent, sonicated for $10 \mathrm{~min}$ at room temperature, and suitably diluted. An appropriate volume was filtered through a 25-mm nylon membrane disposable filter $(0.45-\mu \mathrm{m}$ pore size, $\mu$ clar, Argentina). They were injected in triplicate (RSD $<2.0 \%$ ), and the results averaged. In both cases, the theoretical CIP concentration injected was $7-10 \mu \mathrm{g} / \mathrm{mL}$, and all solutions were used on the day prepared. 
Table 2. Assay Values, Chemical Stability, Dissolution Test, and Price per Tablet

\begin{tabular}{|c|c|c|c|c|c|c|c|}
\hline \multirow{2}{*}{$\begin{array}{l}\text { Storage } \\
\text { Time }\end{array}$} & & \multicolumn{6}{|c|}{ FORMULATION } \\
\hline & & I & II & III & IV & $\mathbf{V}$ & $\mathbf{V} \mathbf{l}^{a}$ \\
\hline \multirow[t]{4}{*}{0} & $\begin{array}{c}\text { Assay } \\
\text { (mean } \pm \mathrm{sd})\end{array}$ & $102.2 \pm 0.2$ & $92.6 \pm 0.4$ & $97.3 \pm 0.1$ & $102.6 \pm 0.2$ & $97.9 \pm 0.2$ & $99.4 \pm 0.1$ \\
\hline & $\mathrm{S}_{1}$ dissolution stage & Fulfill & Fulfill & Fulfill & Fulfill & Not fulfill & Fulfill \\
\hline & $\begin{array}{c}\text { Max. \% dissolved at } 60 \mathrm{~min} \\
(\text { mean } \pm \mathrm{sd})\end{array}$ & $89.6 \pm 2.2$ & $86.1 \pm 2.3$ & $89.0 \pm 2.4$ & $94.2 \pm 3.0$ & $92.0 \pm 4.3$ & $95.8 \pm 2.1$ \\
\hline & Price per tablet (\$Arg.) & 3.19 & 3.29 & 3.90 & 5.14 & 3.92 & 8.65 \\
\hline \multirow[t]{2}{*}{$3 \mathrm{M}$} & $\mathrm{S}_{1}$ dissolution Stage & Fulfill & Not fulfill & Not fulfill & Not fulfill & Not fulfill & Fulfill \\
\hline & $\begin{array}{l}\text { Max. \% dissolved at } 60 \mathrm{~min} \\
\quad(\text { mean } \pm \mathrm{sd})\end{array}$ & $85.7 \pm 3.2$ & $81.5 \pm 2.2$ & $82.0 \pm 4.3$ & $84.9 \pm 1.9$ & $82.8 \pm 3.9$ & $84.9 \pm 0.9$ \\
\hline \multirow[t]{3}{*}{$6 \mathrm{M}$} & $\begin{array}{c}\text { Assay } \\
(\text { mean } \pm \text { sd)/ } \\
\text { ANOVA 0-6 }\end{array}$ & $\begin{array}{c}91.3 \pm 2.4 / \\
*(p=0.0232)\end{array}$ & $\begin{array}{l}93.5 \pm 2.5 / \\
\text { n.s. }\end{array}$ & $\begin{array}{l}94.9 \pm 2.5 / \\
\text { n.s. }\end{array}$ & $\begin{array}{c}94.5 \pm 2.5 / \\
*(p=0.0446)\end{array}$ & $\begin{array}{c}97.3 \pm 2.6 / \\
\text { n.s }\end{array}$ & $\begin{array}{l}95.6 \pm 2.5 / \\
\text { n.s. }\end{array}$ \\
\hline & $\mathrm{S}_{1}$ dissolution stage & Not fulfill & Not fulfill & Not fulfill & Not fulfill & Not fulfill & Fulfill \\
\hline & $\begin{array}{l}\text { Max. \% dissolved at } 60 \mathrm{~min} \\
(\text { mean } \pm \mathrm{sd})\end{array}$ & $86.7 \pm 1.9$ & $83.8 \pm 2.2$ & $85.6 \pm 2.2$ & $84.5 \pm 1.6$ & $85.6 \pm 3.7$ & $88.0 \pm 4.1$ \\
\hline
\end{tabular}

CIP content determination was performed at the beginning of the aging process (time zero) and after 6 months under accelerated-aging conditions $(6 \mathrm{M})$, and the results were compared using ANOVA.

\section{Dissolution Stability Study}

Dissolution studies were performed according to the $B P$ monograph for CIP tablets (2). The dissolution test tolerance indicates that an amount of ciprofloxacin hydrochloride equivalent to not less than $80 \%(Q)$ of the labeled amount of CIP should dissolve in $30 \mathrm{~min}$.

Dissolution testing was carried out on a suitably calibrated USP Apparatus 2 (Erweka DT60) at $50 \pm 1 \mathrm{rpm}$, under sink conditions in $900 \mathrm{~mL}$ of deaerated distilled water at $37 \pm 0.5^{\circ} \mathrm{C}$ for each test (six replicates of each brand). Samples ( $5 \mathrm{~mL}$ ) were withdrawn at $2.5,5,10,15,20$, 30 , and $60 \mathrm{~min}$, with replacement of the same volume of fresh media after each withdrawal, and filtered through blue-ribbon filter paper. Samples were suitably diluted with distilled water and analyzed using UV spectroscopy at $276 \mathrm{~nm}$ (Varian Cary 50). The concentration in each sample was calculated from a CIP standard calibration curve ( $y=0.1146 x-0.0058$; range: $1-8 \mu \mathrm{g} / \mathrm{mL} ; \mathrm{r}$ : 0.9999). Results were averaged, and cumulative drug-release percentages were calculated for dissolution profile estimation.

CIP tablet dissolution behavior was evaluated at time zero and after $3(3 \mathrm{M})$ and $6(6 \mathrm{M})$ months of storage in their original containers, according to $\mathrm{ICH}$ accelerated-aging conditions $\left(40^{\circ} \mathrm{C} / 75 \% \mathrm{RH}\right)$ for Argentinean climatic zone (11). These conditions were obtained using a stability chamber (SCT Pharma, model ICH 830 L, Argentina).

Dissolution profiles were compared using similarity factor $f_{2}(12-15)$ and statistical evaluation of dissolution efficiency (DE). The $f_{2}$ values were calculated only up to the first point at which $85 \%$ release was achieved (13). In cases where more than $85 \%$ of the drug is dissolved within 15 min, dissolution profiles may be accepted as similar without further mathematical evaluation (15). DE is defined as the area under the dissolution curve between two time points expressed as a percentage of the curve at maximum dissolution, $100 \%$, over the same time period (16). DE was calculated from the area under the dissolution curve at $60 \mathrm{~min}$ (measured using the trapezoidal rule) and expressed as a percentage of the area of the rectangle described by $100 \%$ dissolution in the same time.

Each formulation was compared with the reference (sample $\mathrm{VI}$ ) at time $0,3 \mathrm{M}$, and $6 \mathrm{M}$, using both similarity factor $f_{2}$ and ANOVA (Dunnett test). Furthermore, DE values were compared by ANOVA to evaluate the effect of aging conditions on the dissolution stability within each formulation.

\section{RESULTS AND DISCUSSION}

At time zero, CIP average content for all tested tablets ranged from $91.6 \%$ to $103.7 \%$, which was within the 
Table 2. (Continued)

\begin{tabular}{|c|c|c|c|c|c|c|}
\hline \multirow{2}{*}{$\begin{array}{l}\text { Storage } \\
\text { time }\end{array}$} & & \multicolumn{5}{|c|}{ FORMULATION } \\
\hline & & VII & VIII & IX & $\mathbf{x}$ & $\mathbf{X I}$ \\
\hline \multirow[t]{4}{*}{0} & $\begin{array}{c}\text { Assay } \\
\text { (mean } \pm \text { sd) }\end{array}$ & $93.7 \pm 0.04$ & $95.3 \pm 0.04$ & $91.6 \pm 0.04$ & $94.7 \pm 0.05$ & $103.7 \pm 0.15$ \\
\hline & $\mathrm{S}_{1}$ dissolution stage & Fulfill & Fulfill & Not fulfill & Fulfill & Fulfill \\
\hline & $\begin{array}{l}\text { Max. \% dissolved at } 60 \mathrm{~min} \\
(\text { mean } \pm \mathrm{sd})\end{array}$ & $93.8 \pm 2.9$ & $88.8 \pm 3.7$ & $93.5 \pm 2.0$ & $95.1 \pm 3.6$ & $92.3 \pm 7.0$ \\
\hline & Price per tablet (\$Arg) & 4.76 & 4.09 & Hospital sample & Hospital sample & 5.54 \\
\hline \multirow[t]{2}{*}{$3 M$} & $\mathrm{~S}_{1}$ dissolution stage & Not fulfill & Not fulfill & Not fulfill & Not fulfill & Not fulfill \\
\hline & $\begin{array}{l}\text { Max. \% dissolved at } 60 \mathrm{~min} \\
\quad(\text { mean } \pm \mathrm{sd})\end{array}$ & $84.1 \pm 1.6$ & $83.1 \pm 2.3$ & $87.2 \pm 2.0$ & $86.0 \pm 2.5$ & $89.4 \pm 5.0$ \\
\hline \multirow[t]{3}{*}{$6 \mathrm{M}$} & $\begin{array}{l}\text { Assay } \\
(\text { mean } \pm \text { sd)/ } \\
\text { ANOVA } 0-6^{b}\end{array}$ & $\begin{array}{c}101.4 \pm 2.7 / \\
*(p=0.0447)\end{array}$ & $\begin{array}{c}79.4 \pm 2.1 / \\
* *(p=0.0084)\end{array}$ & $\begin{array}{c}98.3 \pm 2.6 / \\
*(p=0.0169)\end{array}$ & $\begin{array}{c}103.3 \pm 2.7 / \\
*(p=0.0464)\end{array}$ & $\begin{array}{c}105.3 \pm 2.8 / \\
\text { n.s. }\end{array}$ \\
\hline & $\mathrm{S}_{1}$ dissolution stage & Not fulfill & Not fulfill & Not fulfill & Not fulfill & Not fulfill \\
\hline & $\begin{array}{l}\text { Max. \% dissolved at } 60 \mathrm{~min} \\
(\text { mean } \pm \mathrm{sd})\end{array}$ & $86.0 \pm 3.9$ & $30.8 \pm 3.1$ & $83.5 \pm 2.3$ & $87.7 \pm 1.7$ & $81.8 \pm 1.8$ \\
\hline \multicolumn{7}{|c|}{$\begin{array}{l}\text { 'Statistical references: } \\
\text { n.s. No significant differences between the compared values } \\
\text { * Significant differences }(0.01<p<0.05)\end{array}$} \\
\hline
\end{tabular}

acceptable USP limits of $90.0-110.0 \%$ (1). After six months of accelerated storage conditions, CIP average content ranged from $91.3 \%$ to $105.3 \%$, which also fulfilled the requirements of USP 30 , with the exception of formulation VIII for which the assay results showed an average value of 79.4\% (Table 2). When ANOVA analysis was applied, statistically significant differences were recorded for assay average values between time zero and $6 \mathrm{M}$ for formulations I, IV, VII, VIII, IX, and X (Table 2). The ANOVA results indicate that there were no statistical differences throughout the stability study for formulations II, III, V, VI (Ref.) and XI. Nevertheless, since the CIP concentration measured in the assay of each sample remained within $90 \%$ of label claim, it could be concluded that the analyzed formulations are chemically stable during the storage time, with the exception of sample VIII.

Most of the formulations met the requirements for $S_{1}$ dissolution stage at time zero, but not at times $3 \mathrm{M}$ and $6 \mathrm{M}$; with the exception of the reference formulation, which fulfilled the dissolution test in $\mathrm{S}_{1}$ stage throughout the stability study. Formulations $\mathrm{V}$ and IX did not fulfill this test at any time during the entire evaluation (Table 2). The maximum percentage dissolved in 60 min agrees with the assay result of the same products throughout the stability study. In contrast, the maximum percentage dissolved at $6 \mathrm{M}$ for formulation VIII was an extremely low value of $30.8 \%$.

Dissolution Technologies | FEBRUARY 2010
All formulation profiles were compared with the reference formulation in terms of DE (ANOVA analysis, Dunnett test) and $f_{2}$, throughout the stability study (Table 3). This comparison was done because of the large price differences between the formulations evaluated (Table 2).

At time zero, the minimum and maximum DE values were 77.48 and 87.58 , with an acceptable associated variability in terms of RSD. Moreover, formulations I, II, V, and XI were considered similar to the reference, both by ANOVA analysis and $f_{2}$ factor. In all these cases, more than $85 \%$ of the drug was dissolved within $15 \mathrm{~min}$, so dissolution profiles were accepted as similar without further mathematical evaluation (15). Instead, formulations III, IV, IX, and X were not similar to the reference, because statistical differences were observed by Dunnett analysis, and $f_{2}$ values were all less than 50 . In most cases, the results from ANOVA were in accordance with those obtained using similarity factor, with the exception of formulations VII and VIII. The results for these formulations were contradictory; they were similar to the reference in terms of $f_{2}$, but there were statistical differences detected by ANOVA analysis (Table 3). This discrepancy can be attributed to the fact that all data were included in ANOVA analysis, but only average data were used for $f_{2}$ determinations.

At time $3 \mathrm{M}$, the minimum and maximum $\mathrm{DE}$ values were 59.60 and 78.09, with an acceptable associated variability. Formulations I, IV, VII, IX, and XI were considered 
Table 3. Dunnett Analysis of DE Values and $f_{2}$ Comparison of Profiles throughout the Aging Study

\begin{tabular}{|c|c|c|c|c|c|c|c|c|c|c|c|c|}
\hline \multirow{2}{*}{$\begin{array}{l}\text { Storage } \\
\text { Time }\end{array}$} & & \multicolumn{11}{|c|}{ FORMULATION } \\
\hline & & I & II & III & IV & V & $\mathbf{V I}^{a}$ & VII & VIII & IX & $\mathbf{x}$ & $\mathbf{X I}$ \\
\hline \multirow[t]{3}{*}{0} & $\begin{array}{c}\text { Mean DE } \\
\text { (RSD) }\end{array}$ & $\begin{array}{l}83.95 \\
(2.99)\end{array}$ & $\begin{array}{l}83.48 \\
(1.38)\end{array}$ & $\begin{array}{l}77.48 \\
(1.42)\end{array}$ & $\begin{array}{l}80.43 \\
(3.12)\end{array}$ & $\begin{array}{l}87.58 \\
(2.84)\end{array}$ & $\begin{array}{l}86.76 \\
(0.78)\end{array}$ & $\begin{array}{l}82.23 \\
(1.41)\end{array}$ & $\begin{array}{l}81.78 \\
(3.62)\end{array}$ & $\begin{array}{l}78.33 \\
(2.45)\end{array}$ & $\begin{array}{l}80.78 \\
(3.87)\end{array}$ & $\begin{array}{l}83.54 \\
(6.07)\end{array}$ \\
\hline & $\begin{array}{l}\text { ANOVA DE } \\
\text { (Dunnett) }^{b}\end{array}$ & n.s. & n.s. & $* *$ & $* *$ & n.s. & $a$ & $* *$ & $* *$ & $* *$ & $* *$ & n.s. \\
\hline & $f_{2}$ & $\cdot$ & • & 42.15 & 45.63 & $\cdot$ & $a$ & $\bullet$ & • & 43.28 & 36.31 & $\cdot$ \\
\hline \multirow[t]{3}{*}{$3 \mathrm{M}$} & $\begin{array}{c}\text { Mean DE } \\
\text { (RSD) }\end{array}$ & $\begin{array}{l}78.09 \\
(1.52)\end{array}$ & $\begin{array}{l}73.78 \\
(2.88)\end{array}$ & $\begin{array}{l}69.29 \\
(1.20)\end{array}$ & $\begin{array}{l}76.42 \\
(3.03)\end{array}$ & $\begin{array}{l}76.50 \\
(1.59)\end{array}$ & $\begin{array}{l}77.60 \\
(1.84)\end{array}$ & $\begin{array}{l}74.32 \\
(4.15)\end{array}$ & $\begin{array}{l}59.60 \\
(7.29)\end{array}$ & $\begin{array}{l}76.16 \\
(2.47)\end{array}$ & $\begin{array}{l}74.94 \\
(2.72)\end{array}$ & $\begin{array}{l}74.54 \\
(3.31)\end{array}$ \\
\hline & $\begin{array}{l}\text { ANOVA DE } \\
\text { (Dunnett) }^{b}\end{array}$ & n.s. & * & $* *$ & n.s. & n.s. & $a$ & n.s. & $* *$ & n.s. & * & n.s. \\
\hline & $f_{2}$ & 53.06 & 71.54 & 39.86 & 58.14 & 48.43 & $a$ & 61.90 & c & 67.66 & 54.65 & 60.39 \\
\hline \multirow[t]{6}{*}{$6 \mathrm{M}$} & $\begin{array}{l}\text { Mean DE } \\
\text { (RSD) }\end{array}$ & $\begin{array}{l}77.85 \\
(1.81)\end{array}$ & $\begin{array}{l}75.21 \\
(1.56)\end{array}$ & $\begin{array}{l}71.41 \\
(3.40)\end{array}$ & $\begin{array}{l}77.00 \\
(2.06)\end{array}$ & $\begin{array}{l}81.19 \\
(2.27)\end{array}$ & $\begin{array}{l}78.02 \\
(2.27)\end{array}$ & $\begin{array}{l}74.55 \\
(3.19)\end{array}$ & $\begin{array}{c}16.12 \\
(10.21)\end{array}$ & $\begin{array}{l}72.64 \\
(1.81)\end{array}$ & $\begin{array}{l}75.18 \\
(3.07)\end{array}$ & $\begin{array}{l}72.27 \\
(1.18)\end{array}$ \\
\hline & $\begin{array}{l}\text { ANOVA DE } \\
\text { (Dunnett) }^{b}\end{array}$ & n.s. & * & $* *$ & n.s. & $* *$ & $a$ & $* *$ & $* *$ & $* *$ & * & $* *$ \\
\hline & $f_{2}$ & 40.94 & 52.71 & 53.52 & 43.17 & 31.29 & $a$ & 47.83 & c & 48.11 & 72.24 & 45.67 \\
\hline & ANOVA $0-3 M^{b}$ & $\begin{array}{c}p= \\
0.0004\end{array}$ & $\begin{array}{c}p= \\
0.0000\end{array}$ & $\begin{array}{c}p= \\
0.0000\end{array}$ & $\begin{array}{c}p= \\
0.0165\end{array}$ & $\begin{array}{c}p= \\
0.0000\end{array}$ & $\begin{array}{c}p= \\
0.0000\end{array}$ & $\begin{array}{c}p= \\
0.0002\end{array}$ & $\begin{array}{c}p= \\
0.0000\end{array}$ & n.s. & $\begin{array}{c}p= \\
0.0033\end{array}$ & $\begin{array}{c}p= \\
0.0000\end{array}$ \\
\hline & ANOVA $3 M-6 M^{b}$ & n.s. & n.s. & n.s. & n.s. & $\begin{array}{c}p= \\
0.0004\end{array}$ & n.s. & n.s. & $\begin{array}{c}p= \\
0.0000\end{array}$ & $\begin{array}{c}p= \\
0.0037\end{array}$ & n.s. & n.s. \\
\hline & ANOVA $0-6 \mathrm{M}^{b}$ & $\begin{array}{c}p= \\
0.0004\end{array}$ & $\begin{array}{c}p= \\
0.0000\end{array}$ & $\begin{array}{c}p= \\
0.0002\end{array}$ & $\begin{array}{c}p= \\
0.0179\end{array}$ & $\begin{array}{c}p= \\
0.0005\end{array}$ & $\begin{array}{c}p= \\
0.0000\end{array}$ & $\begin{array}{c}p= \\
0.0000\end{array}$ & $\begin{array}{c}p= \\
0.0000\end{array}$ & $\begin{array}{c}p= \\
0.0001\end{array}$ & $\begin{array}{c}p= \\
0.0054\end{array}$ & $\begin{array}{c}p= \\
0.0000\end{array}$ \\
\hline
\end{tabular}

${ }^{a}$ Reference formulation

${ }^{b}$ Statistical references:

n.s. no significant difference between the compared values

* $\quad$ significant differences $(0.01<p<0.05)$

** high significant differences $(p<0.01)$

- $\quad>85 \%$ drug was dissolved within $15 \mathrm{~min}$; dissolution profiles were accepted as similar without further mathematical evaluation

'According to the FDA Guidance, the similarity factor is calculated using mean dissolution percentages, but to allow use of mean data, the percent coefficient of variation at the earlier time points (e.g., $15 \mathrm{~min}$ ) should not be more than $20 \%$, and at other time points should not be more than $10 \%$. The similarity factor could not be determined for this formulation because of the high variability associated to the mean dissolution percentages.

similar to, and formulation III was considered different from the reference in both approaches. As was seen at time zero, the results from ANOVA were not in accordance with the similarity factor for formulations II, V, and X.

At time $6 \mathrm{M}$, the minimum and maximum $\mathrm{DE}$ values were 16.12 and 81.19 with an acceptable associated variability. Formulations V, VII, IX, and XI were different from the reference, both by ANOVA analysis and similarity factor determination. Results for formulations I, II, III, IV, and X were not in agreement with the reference for both approaches.

Formulation VIII was considered different from the reference, both at times $3 \mathrm{M}$ and $6 \mathrm{M}$, in terms of ANOVA analysis. The similarity factor could not be determined, considering the high variability associated with the mean dissolution percentages (13-15).

Significant DE decreases were observed between time zero and $3 \mathrm{M}$ ( $p$ values between 0.0000 and 0.0165 ), with

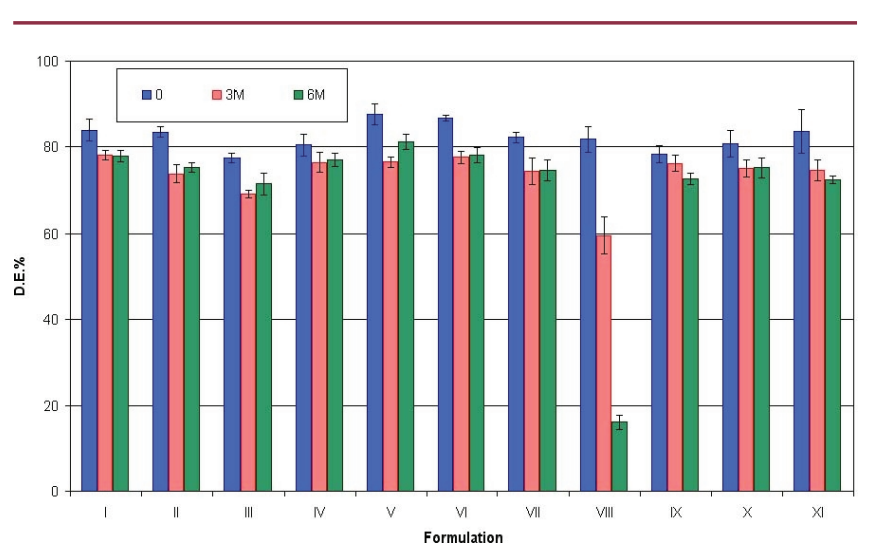

Figure 1.DE evolution throughout the aging study. 


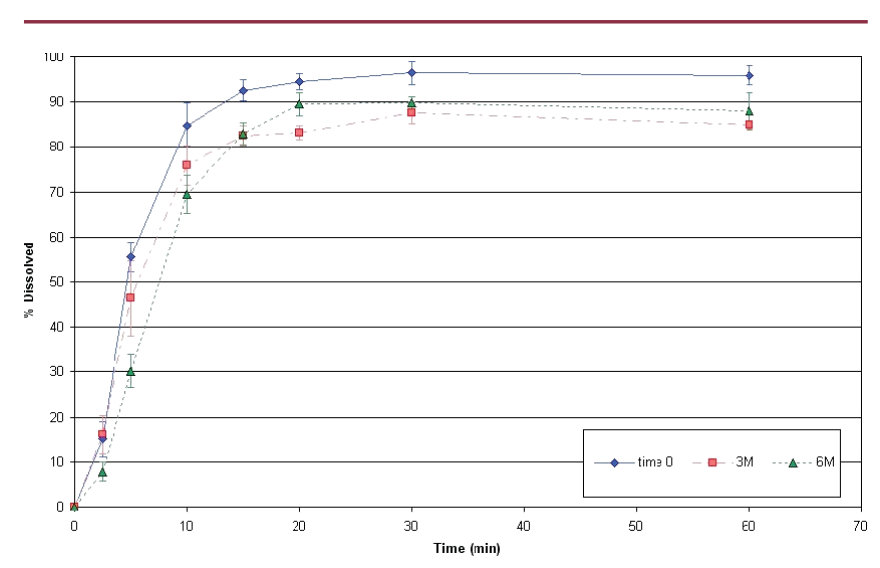

Figure 2. Dissolution profiles of reference formulation VI at the three time points of the accelerated aging study.

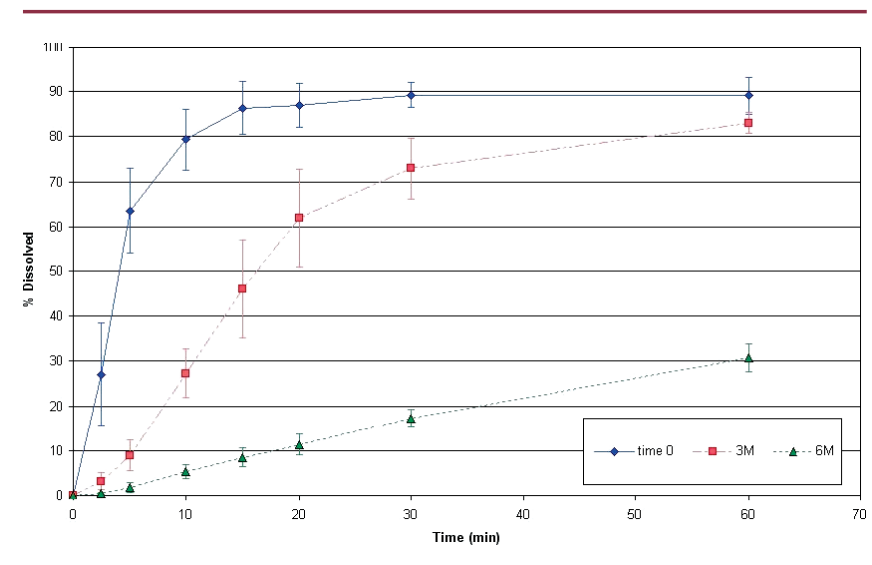

Figure 3. Dissolution profile of formulation VIII at the three time points of the accelerated aging study.

the exception of formulation IX, for which no statistical difference was found. Between times $3 \mathrm{M}$ and $6 \mathrm{M}$, only formulations V, VIII, and IX showed statistical differences in terms of DE, with $p$ values between 0.0000 and 0.0037 . Storage conditions affected the drug-release behavior of all formulations; after $6 \mathrm{M}$ storage, DE was significantly reduced ( $p$ values between 0.0000 and 0.0179 ). In some cases, these reductions in DE were associated with significant differences in the assay result (formulations I, IV, VII-X), but values greater than $90 \%$ of label claim were seen in all formulations except for sample VIII. DE results throughout the aging study can also be seen in Figure 1, in which the significant DE decrease for formulation VIII stands out. However, this sample was not the most economical for the patient in terms of price (Table 2).

CIP in vitro dissolution profiles from formulations $\mathrm{VI}$ and VIII are presented in Figures 2 and 3. Each data point represents an average of the measurements for each formulation. Figure 2 (reference formulation) represents the case of almost no variation in dissolution profiles with aging, while Figure 3 (formulation VIII) shows the highest variation observed for the evaluated formulations.

\section{CONCLUSIONS}

This study examined the effect of accelerated-aging conditions on the performance of CIP tablets. Although storage conditions affected the dissolution behavior of all CIP tablet formulations, they did not have a significant effect on CIP chemical stability. Nevertheless, formulation VIII presented undesirable chemical and dissolution stability performance, as shown by the extremely low CIP content, maximum percentage dissolved, and DE values at $6 \mathrm{M}$.

The aging effects on the release behavior of multisource CIP immediate-release tablets suggest likely implications for drug bioavailability. Nevertheless, the potential impact of these results on the in vivo bioavailability would require further investigation, but it could be anticipated that this attribute would be affected.

\section{ACKNOWLEDGMENTS}

The authors thank Hospital Naval Puerto Belgrano and Hospital Militar for the donation of formulations IX and X.

Noelia Gonzalez Vidal holds a doctoral fellowship of Consejo Nacional de Investigaciones Científicas y Técnicas (CONICET) and Universidad Nacional del Sur (UNS), Argentina.

This work was supported by funds from Universidad Nacional del Sur, Argentina (Project number: PGI 24/B139).

\section{REFERENCES}

1. United States Pharmacopoeia and National Formulary USP 30-NF 25; The United States Pharmacopeial Convention, Inc.: Rockville, MD, 2007.

2. The British Pharmacopoeia, Vol. III. The Stationary Office: London, 2008.

3. Ciprofloxacin Monograph. In The Merck Index, 13th ed.; O’Neil, M. J., Smith, A., Heckelman, P. E., Budavari, S., Eds.; Merck:Whitehouse Station, NJ, 2001.

4. Campoli-Richards, D. M.; Monk, J. P.; Price, A.; Benfield, P.; Todd, P. A.; Ward, A. Ciprofloxacin: A review of its antibacterial activity, pharmacokinetic properties and therapeutic use. Drugs 1988, 35, 373-447.

5. Amidon, G. L.; Lennernäs, H.; Shah, V. P.; Crison, J. R. A theoretical basis for a Biopharmaceutic Drug Classification:The correlation of in vitro drug product dissolution and in vivo bioavailability. Pharm. Res. 1995, 12 (3), 413-420.

6. Lindenberg, M.; Kopp, S.; Dressman, J. B. Classification of orally administered drugs on the World Health Organization Model List of Essential Medicines according to the Biopharmaceutics Classification System. Eur. J. Pharm. Biopharm. 2004, 58, 265-278.

7. Saville, D. J. Influence of storage on in vitro release of ibuprofen from sugar coated tablets. Int. J. Pharm.

2001, 224, 39-49. 
8. Pandit, J. K.; Tripathi, M. K.; Babu, J. R. Effects of disintegrants on the dissolution stability of solid oral dosage forms. Pharmazie 1997, 52, 538-540.

9. Mathews, R. B. Regulatory aspects of stability testing in Europe. Drug Dev. Ind. Pharm. 1999, 25, 831-856.

10. Murthy, K. S.; Ghebre-Sellassie, J. Current perspectives on the dissolution stability of solid oral dosage forms. J. Pharm. Sci. 1993, 82 (2), 113-126.

11. International Conference on Harmonization. Stability Testing of New Drug Substances and Products, Q1A(R2); ICH Harmonised Tripartite Guideline; Geneva, Switzerland, 2003. http://www.ich.org/LOB/media/ MEDIA419.pdf (accessed Jan 16, 2010).

12. Moore, J.W.; Flanner, H. H. Mathematical comparison of dissolution profiles. Pharm. Technol. 1996, 20 (6), 64-75.

13. Dissolution Testing of Immediate-Release Solid Oral Dosage Forms; Guidance for Industry; U.S.

Department of Health and Human Services, Food and Drug Administration, Center for Drug Evaluation and Research (CDER), U.S. Government Printing Office:Washington, DC, 1997. http://www.fda.gov/downloads/Drugs/ GuidanceComplianceRegulatorylnformation/ Guidances/ucm070237.pdf (accessed Jan 16, 2010).

14. Waiver of In Vivo Bioavailability and Bioequivalence Studies for Immediate-Release Solid Oral Dosage Forms Based on a Biopharmaceutics Classification System; Guidance for Industry; U.S. Department of Health and Human Services, Food and Drug Administration, Center for Drug Evaluation and Research (CDER), U.S. Government Printing Office:Washington, DC, August 2000.http://www.fda.gov/downloads/Drugs/ GuidanceComplianceRegulatorylnformation/ Guidances/ucm070246.pdf (accessed Jan 16, 2010).

15. The European Agency for the Evaluation of Medicinal Products, Evaluation of Medicines for Human Use. Note for Guidance on the Investigation of Bioavailability and Bioequivalence, CPMP/EWP/QWP/1401/98; Committee for Proprietary Medicinal Products, European Medicines Agency: London, 2001. http://www.emea.europa.eu/pdfs/human/qwp/ 140198enfin.pdf (accessed Jan 16, 2010).

16. Khan, K. A. The concept of dissolution efficiency.J. Pharm. Pharmacol. 1975, 27, 48-49. 